Original Paper

\title{
Penyuluhan Mengenai Pola Makan Sehat dan Seimbang untuk Pencegahan Anemia Pada Kader Posyandu Di Puskesmas Nipah, Kabupaten Lombok Utara
}

\author{
Rifana Cholidah $^{1 *}$, Ida Ayu Eka Widiastuti ${ }^{1}$, Ima Arum Lestarini ${ }^{1}$ \\ ${ }^{1}$ Fakultas Kedokteran Universitas Mataram, Indonesia
}

DOI: $10.29303 /$ jpmpi.v2i2.368

Sitasi: Cholidah, R., Widiastuti, I. A. E., Lestarini, I. A. (2019). Penyuluhan Mengenai Pola Makan Sehat dan Seimbang untuk Pencegahan Anemia Pada Kader Posyandu Di Puskesmas Nipah, Kabupaten Lombok Utara. Jurnal Pengabdian Magister Pendidikan IPA (JPMPI). (2) 2. pp. 114-117

*Corresponding Author: Rifina Cholidah, Fakultas Kedokteran Universitas Mataram, Indonesia; Email: rifana.cholidah@gmail.com

\begin{abstract}
Abstrak: Pengabdian ini bertujuan meningkatkan pengetahuan kader mengenai pola makan sehat dan seimbang untuk pencegahan anemia pada kader posyandu di Puskesmas Nipah, Kabupaten Lombok Utara. Metode pelaksanaan pengabdian ini meliputi penyuluhan mengenai pola makan sehat dan seimbang untuk pencegahan anemia pada kader posyandu di Puskesmas Nipah, Desa Malaka, Kecamatan Pemenang, Kabupaten Lombok Utara. Penyuluhan disampaikan melalui metode ceramah dan diskusi. Pemateri adalah tim pengabdian masyarakat dari FK Unram beserta 1 orang mahasiswa mahasiswa semester 7. Setelah pengetahuan kader meningkat maka dilakukan evaluasi penerapan hasil penyuluhan berupa tindakan para kader posyandu untuk menyampaikannya kepada masyarakat, terutama pada ibu yang memiliki anak usia sekolah dan juga pada ibu hamil dan menyusui. Pada kegiatan ini disimpulkan anemia defisiensi besi adalah salah satu kelainan akibat kekurangan zat gizi besi yang dapat terjadi baik di negara maju maupun negara berkembang. Kader Posyandu mempunyai peran yang penting sebagai penyuluh dan fasilitator di lapangan yang berinteraksi langsung dengan masyarakat sekitar khususnya para ibu hamil, menyusui dan ibu yang memiliki anak usia sekolah. Penyuluhan mengenai pola makan sehat dan seimbang untuk pencegahan anemia adalah salah satu cara pencegahan anemia dengan cara peningkatan pengetahuan kader posyandu tentang gejala awal anemia, sumber-sumber makanan yang kaya akan zat besi dan penerapan pola makan sehat dan seimbang.
\end{abstract}

Kata Kunci: Penyuluhan; Pola Makan Sehat dan Seimbang; Pencegahan Anemia.

\section{Pendahuluan}

Anemia adalah suatu kondisi dimana jumlah sel darah merah (dan berpengaruh kepada kapasitas daya angkut oksigen) tidak mencukupi kebutuhan fisiologis tubuh (WHO, 2011). Anemia merupakan salah satu masalah kesehatan yang sering terjadi baik dinegara maju maupun di negara berkembang (Mira et al, 1996; Aggett et al., 2002; Thompson et al., 2008). Asupan makanan yang adekuat akan dapat menyediakan energi, nutrisi, dan serat yang cukup untuk dapat memelihara kesehatan tubuh. Zat besi adalah mineral yang merupakan bagian dari hemoglobin dan myoglobin yang berperan sangat penting pada distribusi oksigen dalam tubuh. Zat besi juga merupakan koenzim pada banyak reaksi metabolik yang berperan dalam produksi energi (Thompson et al., 2008).

Rekomendasi kecukupan zat gizi besi dari Kementrian Kesehatan untuk anak laki-laki usia 1012 tahun adalah $13 \mathrm{mg} /$ hari dan wanita usia 10-12 tahun adalah $20 \mathrm{mg} /$ hari (Permenkes, 2013). Berdasarkan Riskesdas tahun 2013 di dapatkan anemia gizi besi masih menjadi masalah kesehatan masyarakat dengan angka kejadian anemia pada anak usia 5 - 12 tahun sebesar $29 \%$. Anemia yang disebabkan karena kurangnya zat gizi ditandai dengan adanya gangguan pada produksi hemoglobin baik karena kurangnya asupan zat besi atau karena gangguan absorpsi (Almatsier, 2010). 
Hal ini dapat disebabkan karena kurangnya pemenuhan zat gizi untuk pembentukan darah, seperti defisiensi zat besi, asam folat ataupun vitamin B12 (Sulistyoningsih, 2010). Faktor gizi berperan penting dalam mengembangkan potensi sumber daya manusia dan kualitas hidup yang lebih baik dengan harapan hidup yang lebih panjang (Thompson et al., 2008). Adapun dampak anemia bagi anak usia sekolah dasar dapat menyebabkan terganggunya tumbuh kembang fisik, rendahnya daya tahan tubuh terhadap penyakit, rendahnya tingkat kecerdasan anak, rendahnya prestasi belajar/kerja, dan juga rendahnya prestasi olahraga. Lebih lanjut, anemia pada anak dapat berdampak pada menurunnya kemampuan dan konsentrasi belajar, menghambat pertumbuhan sel tubuh dan juga sel otak sehingga dapat menimbulkan gejala letih, lemah, lesu, pucat sehingga dapat menurunkan kebugaran dan prestasi belajar (Sirajuddin \& Masni, 2015). Berdasarkan Riskesdas tahun 2013 di dapatkan anemia gizi besi masih menjadi masalah kesehatan masyarakat dengan angka kejadian anemia pada anak usia 5 12 tahun sebesar $29 \%$.

Anemia yang disebabkan karena kurangnya zat gizi ditandai dengan adanya gangguan pada produksi hemoglobin baik karena kurangnya asupan zat besi atau karena gangguan absorpsi (Almatsier, 2010). Hal ini dapat disebabkan karena kurangnya pemenuhan zat gizi untuk pembentukan darah, seperti defisiensi zat besi, asam folat ataupun vitamin B12 (Sulistyoningsih, 2010). Faktor gizi berperan penting dalam mengembangkan potensi sumber daya manusia dan kualitas hidup yang lebih baik dengan harapan hidup yang lebih panjang (Thompson et al., 2008).

Anemia yang lain biasanya disebabkan oleh adanya defisiensi zat-zat mikronutrien. Ada tiga jenis anemia yang berhubungan dengan defisiensi mikronutrien yaitu: anemia defisiensi besi (mikrositik anemia), anemia pernisiosa, dan makrositik anemia (Thompson et al, 2008). Sel darah merah yang disintesis dalam kondisi rendah zat besi ukurannya lebih kecil dibanding sel darah merah normal. Sel darah merah jenis ini juga mengandung hemoglobin yang lebih rendah untuk mengangkut oksigen ataupun untuk mentransfer elektron dalam menghasilkan energi. Gejala yang ditimbulkan dari anemia mikrositik adalah rendahnya performa kerja, kelelahan, kulit yang pucat, menurunnya sistem imum, menurunnya fungsi saraf dan kognitif, dan menurunnya ingatan
(Thompson et al, 2008). WHO memperkirakan bahwa pada tahun 2010 sekitar 2 milyar penduduk dunia, atau sekitar $30 \%$ dari total penduduk, menderita anemia. Banyak dari kasus tersebut disebabkan oleh defisiensi zat besi yang berasal dari daerah yang miskin sumber zat besi, dan juga disebabkan oleh kekambuhan penyakit-penyakit infeksi seperti Malaria, HIV/AIDS, infeksi cacing tambang, dan infeksi lain seperti TBC (Oti-Boateng et al., 1998).

Adapun dampak anemia bagi anak usia sekolah dasar dapat menyebabkan terganggunya tumbuh kembang fisik, rendahnya daya tahan tubuh terhadap penyakit, rendahnya tingkat kecerdasan anak, rendahnya prestasi belajar/kerja, dan juga rendahnya prestasi olahraga. Lebih lanjut, anemia pada anak dapat berdampak pada menurunnya kemampuan dan konsentrasi belajar, menghambat pertumbuhan sel tubuh dan juga sel otak sehingga dapat menimbulkan gejala letih, lemah, lesu, pucat sehingga dapat menurunkan kebugaran dan prestasi belajar (Sirajuddin \& Masni, 2015).

Selain pada anak usia sekolah, anemia juga sering terjadi pada ibu hamil dan menyusui. Hal ini disebabkan karena kebutuhan ibu akan zat besi meningkat pada saat kehamilan dan menyusui. Pencegahan anemia dapat berupa pola makan yang seimbang. Adapun zat besi dapat diperoleh dari makanan sehari-hari seperti daging, ikan, unggas, sayuran seperti bayam, kacangan-kacangan dan juga makanan yang terfortifikasi. Selain makanan yang kaya akan zat besi, anemia juga dapat dicegah dengan banyak mengkonsumsi makanan yang mengandung asam folat seperti kacang-kacangan, hati, dan juga sayuran hijau, seperti sayur bayam. Makanan yang kaya kandungan vitamin B12 seperti susu, produk olahan susu, daging juga sangat baik dikonsumsi untuk pencegahan anemia (Thompson et al., 2008).

\section{Metode Pelaksanaan}

Metode pelaksanaan pengabdian ini meliputi penyuluhan mengenai pola makan sehat dan seimbang untuk pencegahan anemia pada kader posyandu di Puskesmas Nipah, Desa Malaka, Kecamatan Pemenang, Kabupaten Lombok Utara. Penyuluhan disampaikan melalui metode ceramah dan diskusi. Pemateri adalah tim pengabdian masyarakat dari FK Unram beserta 1 orang mahasiswa mahasiswa semester 7. Penyuluhan 
diadakan pada hari Sabtu tanggal 7 September 2019 di Puskesmas Nipah jam 08.00 Wita. Setelah pengetahuan kader meningkat maka dilakukan evaluasi penerapan hasil penyuluhan berupa tindakan para kader posyandu untuk menyampaikannya kepada masyarakat, terutama pada ibu yang memiliki anak usia sekolah dan juga pada ibu hamil dan menyusui.

\section{Hasil dan Pembahasan}

Kegiatan pengabdian ini berlangsung pada hari Sabtu tanggal 7 September 2019 di Ruang pertemuan lantai 2 Puskesmas Nipah. Kegiatan ini dihadiri oleh 3 orang tim penyuluh Fakultas Kedokteran Unram beserta 1 orang mahasiswa semester 7. Acara dibuka sekitar pukul 08.00 wita. Peserta mulai memenuhi ruangan sekitar pukul 08.30, dikarenakan daerah rumah mereka cukup jauh dari Puskesmas dan sebagian besar kader berprofesi sebagai ibu rumah tangga. Hadir 27 orang kader dari 10 Posyandu binaan PKM Nipah. Selanjutnya kegiatan pengabdian ini terdiri dari beberapa tahap kegiatan, yaitu:

1. Pre test

Sebelum kegiatan penyuluhan dimulai, dilakukan pre test untuk mengetahui pengetahuan pendahuluan peserta tentang apa itu anemia, ciriciri penderita anemia dan sumber makanan apa saja yang banyak mengandung zat besi untuk pencegahan anemia. Didapatkan skor rerata pre test adalah 66

2. Penyuluhan materi inti menggunakan powerpoint yang menjelaskan tentang definisi anemia, cara mendiagnosa anemia, gejala anemia dan sumber makanan yang kaya akan zat besi untuk mencegah terjadinya anemia.

3. Post test

Kegiatan penyuluhan diakhiri dengan melakukan kegiatan post test kepada peserta apakah terdapat peningkatan pengetahuan pendahuluan peserta. Didapatkan skor rerata post test adalah 78, Dari skor tersebut mengindikasikan adanya peningkatan pengetahuan peserta.

\section{Kesimpulan}

Anemia defisiensi besi adalah salah satu kelainan akibat kekurangan zat gizi besi yang dapat terjadi baik di negara maju maupun negara berkembang. Kader Posyandu mempunyai peran yang penting sebagai penyuluh dan fasilitator di lapangan yang berinteraksi langsung dengan masyarakat sekitar khususnya para ibu hamil, menyusui dan ibu yang memiliki anak usia sekolah. Penyuluhan mengenai pola makan sehat dan seimbang untuk pencegahan anemia adalah salah satu cara pencegahan anemia dengan cara peningkatan pengetahuan kader posyandu tentang gejala awal anemia, sumber-sumber makanan yang kaya akan zat besi dan penerapan pola makan sehat dan seimbang.

\section{Saran}

Dari jawaban soal pre test dan post test didapatkan bahwa pengetahuan kader posyandu tentang definisi anemia, gejala anemia dan pola makan sehat dan seimbang untuk pencegahan anemia masih rendah sehingga diperlukan sosialisasi yang menyeluruh di semua fasilitas kesehatan. Diperlukan adanya pelatihan lanjutan tentang cara membuat nemu makanan sehat dan seimbang yang mencakup sumber-sumber makanan yang kaya akan zat besi untuk mencegah kejadian anemia di lingkungan sekitar tempat para kader posyandu bertugas.

\section{Daftar Pustaka}

Aggett, P. J., Agostoni, C., Axelsson, I., Bresson, J. L., Goulet, O., Hernell, O., Micheli, J. L. (2002). Iron metabolism and requirements in early childhood: do we know enough?: a commentary by the ESPGHAN Committee on Nutrition. Journal of pediatric gastroenterology and nutrition, 34(4), 337

Almatsier, S. 2010. Prinsip Dasar Ilmu Gizi. Jakarta: Gramedia Pustaka Utama.

Departemen Kesehatan Republik Indonesia., 2013. Riset Kesehatan dasar 2013. Jakarta: Departemen Kesehatan Republik Indonesia.

Mira, M., Alperstein, G., Karr, M., Ranmuthugala, G., Causer, J., Niec, A., \& Lilburne, A. M. (1996). Haem iron intake in 12-36 month old children depleted in iron: case-control study. BMJ, 312(7035), 881

Oti-Boateng, P., Seshadri, R., Petrick, S., Gibson, R., \& Simmer, K. (1998). Iron status and dietary iron intake of 6-24 month old 
children in Adelaide. Journal of paediatrics and child health, 34(3), 250-253.

Thompson, J.L., Manore, M.M. and Vaughan, L. (2008). The Science of Nutrition: What disorders can result from inadequate intakes of nutrients involved in blood health?, Benjamin Cummings

World Health Organization, 2011. Haemoglobin concentration for the diagnosis of anaemia and assessment 